\title{
Development of Accounting Information System Modul Learning in Universitas Persada
} Indonesia

\author{
Endang Suparman, Suyitno Muslim ,Nurdin Ibrahim, Ayu Rahmayanti, Jhoni Lagun Siang
}

\begin{abstract}
The research aims to produce that accounting information systems intruductional modul for college of department of information in indonesia administrasion foundation (YAI). The research was implementation at the department of information YAI for 1 year 2 months in the research and development $(R \& D)$ methode with Dick And Carey model of design. The accounting information systems learning consepts was collection of resources,designedto transform financial and other data into information from Bodnar. The results indicated that 30 respondens in field trials produce until the finished of product module accounting was effective and efficient and had an appeal. Results of study subjects accounting information system can be increased after using the accounting information system model that availability of accounting information system model can be used as a source of intructional for college of department of information in institute administration of indonesia. The development of accounting information systems learning module is very important to help teaching process. Therefore the Persada Indonesia YAI is trying to develop it. This module is using ADDIE model, Gerlach and Ely, J.E Kemp, Bella H Banathy, MPI model, Borg and Gali, Dick and Carey model The result area Students are obtaining learning resources for self-study, Students are more eager to learn, because already available SIA print module, Student learning outcomes have increased finally Based on the results of interviews with lecturers SIA module developed to give a positive impact for lecturers and students.
\end{abstract}

Index Terms: Accounting information systems, Interaction, Approch contextual, Module printed.

\section{INTRODUCTION}

Higher Education Competition both PTN and PTS is currently tight, sharp almost no limit. Universities that are unable to compete fairly and openly will be uprooted by the

Revised Manuscript Received on September 22, 2019

Endang Suparman, Departmen of Educational Technology Universitas Negeri Jakarta, RawamangunMuka Street, Rawamangun, Pulogadung, East Jakarta, 13220, Indonesia, and Lecturer at BRI Corporate University., endangsuparman264@gmail.com,

Suyitno Muslim, Departmen of Educational Technology Universitas Negeri Jakarta, RawamangunMuka Street, Rawamangun, Pulogadung, East Jakarta, 13220, suyitno@unj.ac.id,

Nurdin Ibrahim, Departmen of Educational Technology Universitas Negeri Jakarta, RawamangunMuka Street, Rawamangun, Pulogadung, East

Jakarta, 13220, nurdin1349@yahoo.com,

Ayu Rahmayanti, Departmen of Educational Technology Universitas Negeri Jakarta, RawamangunMuka Street, Rawamangun, Pulogadung, East Jakarta, 13220, ayurahmayanti@gmail.com

Jhoni Lagun Siang, Teacher at SMP Negeri 11 Tidore Kepulauan, Jl. Lintas Halmahera, Kota Tidore Kepulauan, Maluku Utara, 97852, Indonesia, jhonicinta@gmail.com circumstances. Similarly, what happens in the learning conditions of SIA in Informatics Engineering Program Faculty of Engineering UPI YAI has not shown the process of student-centered learning in creating knowledge and own pemehaman. Available learning materials have not met the real needs of students. Until now the development process of teaching materials that really fit the demands in accordance with the principles of contextual learning has not been done.

The implementation of the course of accounting information system (SIA) at UPI YAI Faculty of Engineering is very important and necessary, because the course of accounting information system serves to provide knowledge, attitude, and skills to the students about the principles and application of accounting information system. Informatics Engineering Program UPI YAI as the organizer of the recovery. Accounting Information System (SIA) has a clear vision and mission towards achieving the objectives of the SIA lecture. SIA courses generally aim to provide knowledge, attitudes, and intellectual skills in the design of information systems, both regarding transaction processing systems and information processing systems. Taking into account the ideal conditions and facts that occur in the learning of SIA in Informatics Engineering Program UPI YAI, especially the availability of teaching materials that meet the needs of students, it is considered necessary and important to conduct research model development to determine the actual conditions of course learning process SIA with the title "Development of Accounting Information System Learning Module."

The focus of research is the development of learning accounting information system (SIA) module.

The formulation of research development problems are as follows.

1. How is SIA learning at UPI YAI today?

2. How is the development of SIA learning module in UPI YAI?

3. How is the effectiveness of SIA learning module in UPI YAI?

The results of this study are practically expected to contribute thoughts to problem solving related to the problem of effective learning model for learning activities of accounting information system (SIA). Furthermore, the results of this study is expected to be a reference for making SIA learning model by lecturers. 


\section{LITERATURE REVIEW}

\section{A. Modul}

The module is a learning material that is structured with the aim that students can learn independently without or with limited guidance from the instructor. Modules as self-learning materials can be defined as a learning process related to certain discussion units that are arranged systematically, operationally and directed to be used by learners along with guidelines for their use for learners (Ibrahim, 2010). Ibrahim (2010), interpreting the module as a component of independent learning material that includes all learner needs including learning goals, guidelines for use, material descriptions, learning progress, learning evaluation, improvement programs and follow-up (Ibrahim, 2010).

Smaldino, Lowther and Russell, (2012) define learning modules as learning that are packaged into one whole unit that is designed to be used alone or a group of learning without teacher's presence (Smaldino, Lowther and Russell, 2012). Thus it can be concluded that the module is one form of learning material that is packaged intact and systematically that contains a set of planned learning experiences and is designed to help students master specific learning goals. Modules can be used as one of the learning materials to facilitate independent or conventional learning.

\section{B. Model}

Reiser (2007) describes the development of learning modules as an analysis, design, construction, implementation, evaluation and management of learning and non learning process and resources to improve learning and performance in various situations, educational institutions and locations (Reiser, 2007). Furthermore Dick and Carey (2009), describes the development of learning at least consists of five main activities, namely: (1) Analyze the learning conditions and needs of students; (2) designing a series of effective, efficient, and relevant environmental specifications; (3) develop all materials for all students and materials management; (4) implementation of the results of the learning design; and (5) formative and summative evaluation of development outcomes (Dick, Carey, \& Carey, 2009). Gustasfon and Robert (2002), describe learning as a systematic process in which all components (teachers, study participants, learning materials and learning environment) are important for learning success. Dick and Carey state that the system is technically the interconnected parts and all of these parts work together to achieve the intended purpose (Gustafson, dan Branch, 2015).

Associated with the model helps the lecturer conceptualize a process or system. Models help to simplify complexity to real situations with common steps that can be applied in different circumstances. An ideal model of learning is a concept and practice that can facilitate the learning process undertaken lecturers with their students. Joyce et al (2009) describes a teaching model that is truly a learning model, as we help students acquire information, ideas, values, ways, thinking, and average express themselves, teaching how to learn. In fact, the most important long-term outcome of learning allows students to increase their ability to learn more easily and effectively in the future, both because of the knowledge and skills they have acquired and the more mastery they have gained (Bruce Joyce, Marsha Weil, 2009). The teaching model is a description of the learning environment, including the teacher's behavior when using the model. Models have many uses, ranging from lesson planning, teaching materials and curriculum. Miarso (2009) describes the model as a reference that provides complete direction for the learning designer. In this case it is possible to interpret the narrative model into graphical form, or vice versa (Miarso, 2009). Prawiradilaga (2012) explains the model also means as the appearance of a regular or systematic work procedures, and contains the thought of a description or explanation following suggestions (Prawiladilaga, 2012).

Starting from some of these views, the model in principle has structured elements that describe a plot and guidelines or steps to perform a work in this case of learning. Model serves as a reference, guidance, or guidance that can be used to guide the lecturer in designing the learning system so that ultimately obtained the design of effective and measurable learning system to be implemented. Of the various models of instructional design, there is no model of the most powerful learning design. Therefore, in determining the design model for developing a learning program depends on the lecturer's consideration as the designer of the model to be used or chosen. In this development research use Dick and Carey's learning model. Dick and Carey's model interprets the following: 1) performance goals: a statement of what the learners expect by performing and completing a particular learning; this condition is expressed in the form of observable activity; 2) learning analysis, ie procedures to identify relevant skills and subordinate skills of learners as well as the information required of the students to achieve the objectives; and 3) learning strategy, that is the whole activity plan to achieve the learning objectives; including the sequence of instructional activities that lead to instructional goals.

It is these components which in subsequent developments in the Dick and Carey models are systematically developed in ten stages. In the implementation of this model using a system approach (system approach) is a procedural system that works with the principle of a stage will receive input from the previous stage and produce output for the next stage, so that all components work together to meet and produce an effective learning. The model comes with a formative evaluation stage that can help in determining whether something is wrong and how to improve and / or improve the program being developed.

Gustasfon and Robert, (2002) describe this model focusing on the design of learning objectives by asking for needs assessment and documentation of clear and measurable learning objectives(Branch, 2002). 
By looking at the development of learning as a systematic process we capture the role of each component and through formative evaluation can be identified what correction should be done to ensure the learning objectives are met. The model developed in Learning Accounting Information System (SIA) is Dick and Carey model as stated in the following figure:

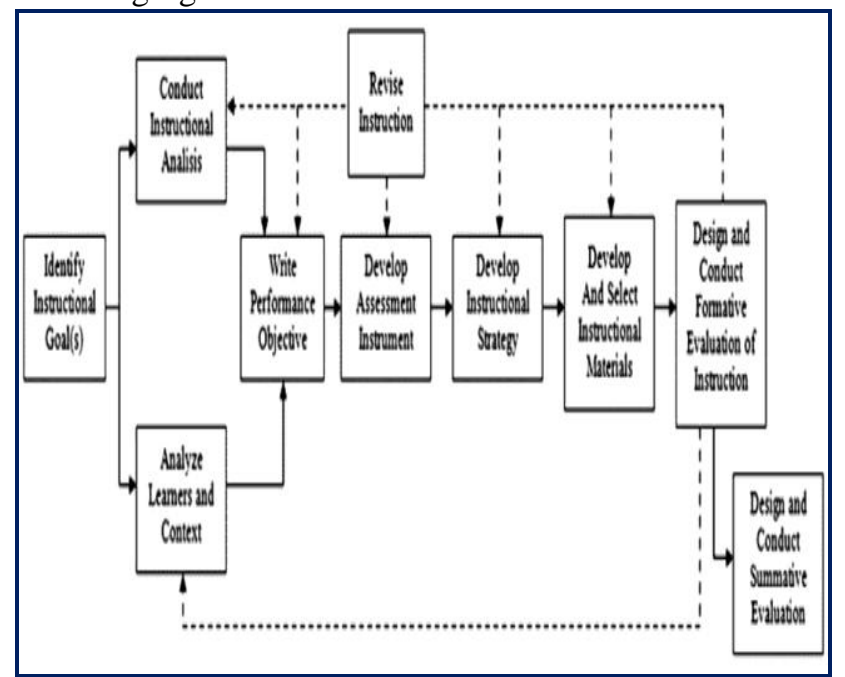

Fig.1. Dick and Carey model

The Dick and Carey model development steps consist of the following 10 steps:

1. Identify the general purpose of learning (assess needs to ldentify goal (s)

2. Implement a learning instruction (conduct instructional analysis)

3. Identify the student's character (analyze learners and contexts)

4. Write down the purpose of learning (write performance objectives)

5. Develop reference criteria for the test (develop assessment instruments)

6. Developing instructional strategies (develop instructional strategy)

7. Choosing and developing learning materials (develop and select instructional materials)

8. Design and conduct formative evaluation of instruction.

9. Revise the design of the learning system (revise instruction).

10. Conducting summative evaluation (design and conduct summative evaluation).

Using Dick and Carey's model, since the development of accounting information system module for faculty of accounting information system requires concrete, systematic, real, and easy to apply steps, either by designer or by user. The characteristic of developing such modules will be in accordance with the Dick and Carey model development steps that have clarity at every stage, are easy to implement, detailed, and easy to follow. Dick and Carey models also have revision activities ranging from learning analysis steps to the next phase or step. Thus, the revision step is relevant to the development of accounting information system modules that require improvement in every step of development, so that a reliable, tested, and reliable product can be obtained by all circles anywhere and anytime. The functions of the SIA module are: (1) overcoming the weaknesses of traditional learning systems; (2) improving learning motivation; (3) improving the creativity of lecturers in preparing the design of a better and effectiveness learning system; and (4) realizing the principle of continuous learning.

Based on that view, where the learning activity is an effort to manage the environment deliberately so that someone to establish themselves in a certain positive under certain conditions. This means that learning is actually more related to the utilization of the learning environment in such a way as to enable students to learn. Similarly, the SIA is an information system that uses computer technology in managing data or corporate transactions into a precise, accurate, and relevant information in decision making.

Manual data processing is no longer relevant to. Computers become the company's primary choice in dealing with complexity and complexity of data or corporate transactions. In the accounting information system, data is processed by a computer commonly referred to as electronic data processing. In the data organization, it is done through two traditional approaches and database approach. Traditional approaches relate to data management where data sources are collected in separate files and unrelated to each other. Usually each file is designed for a particular application. database approach, can be viewed from several points of view.

Based on the above description, the design of the learning system in this research is a model that represents the design of learning system involving the components in the learning process as well as the interrelationship with each other starting from setting goals and objectives, analyzing the resources, designing a plan action, and continuous evaluation and program modification.

In the meantime, the effectiveness of the developed module lies in its practicality in its operational. This SIA module in addition to applying the principles of adult learning and learning, as well as in pengoperasionalannya can be done lecturers anywhere and anytime. An interesting and online module design can foster the interest and motivation of lecturers to read and perform performance. lecturers can communicate and discuss, share their knowlegde with other users or resource persons about the design of learning system. Available computer facilities that provide opportunities for lecturers to gain experience and knowledge to enhance knowledge, creativity, and attitudes in developing and designing learning systems.

Development of learning system design module for lecturer of Information System using Dick and Carey design model which collaborated with Trollip and Alessi media development model. The use of Dick and Carey developers model considers aspects of the advantages and disadvantages of the model to be developed.

Published By: Blue Eyes Intelligence Engineering \& Sciences Publication 
The developed module is a product that can be used on a wide scale. This is relevant to the characteristic Dick and Carey models that can be used for the development of a broad-impact model, involving the team, and being systematized.

The interactive accounting system development module has three conditions, each of which has its own completeness in each stage, each stage containing various issues aimed at performing the action. The three completeness are standardization, continuous evaluation, and management project. These three stages are poured in the form of planning, design and development.

In general, the purpose of this research is to develop a teaching material in the form of module for lecturer of Accounting Information System in designing learning system. Specifically, the purpose of this study is to produce products in the form of SIA learning modules with which can improve the ability of students.

\section{METHODOLOGY}

The purpose of this study is 1) to find out the learning process of Accounting Information Systems (SIA) of the Informatics Engineering Department at the University of Persada Indonesia YAI, 2) to develop teaching materials in the form of an effective module of Accounting Information Systems (AIS) courses, 3) to obtain data empirically about the effectiveness of the Accounting Information System (SIA) learning print module developed in improving the learning outcomes of Informatics Engineering students at the University of Persada Indonesia YAI.

This research can be said as Research and Development. Research and development methods are methods used to produce certain products, and test the effectiveness of these products.(Sugiyono, 2015)

This research is a research and development based on The R \& D cycle of Borg and Gall for the research phase and its development follows the stages of Dick, Carey, and Carey. Research and Development ( $R$ and D) is a combination of qualitative and quantitative approaches, especially to bridge the gap between research and educational practice. (Semiawan, 2007). Research and Development is used to design new products and procedures, then apply research methods for field trials, evaluate and refine products and procedures to meet the criteria of effective, quality and standardized. ( Borg \& Gall, 2007)

The research was conducted in Informatics Engineering UPI YAI. The timing of the development research commences from March to December 2013. The trial of development products for face-to-face is done in the form of workshops. 3. Workshops are conducted in an effort to provide knowledge and understanding to users or test subjects in using the module. In addition to face-to-face meetings in the form of workshops.

The approach taken in this development research is a systemic approach to developing product-oriented learning using the development models Dick, Carey, and Carey. The stages of developing learning modules are carried out according to the procedure of research and development of
Borg \& Gall models, there are five main stages, namely: 1) doing analysis of developed products, 2) developing initial products, 3) expert validation and revision, 4) small-scale field trials and product revisions, and 5) large-scale field trials and final products.

\section{RESULTS AND FINDINGS}

Still found lecturers who have not done student behavior analysis and analysis of learning well. This may be the result of a lecturer who does not have a complete curriculum and content standards that serve as a lesson or a minimal understanding of the importance of learning and learners' analysis, thus making the lecturers unable to design a good learning system. Also found lecturers who do not do learning analysis and design it well. Of course this will affect the quality of learning in the classroom. As a result of all this, it could be that learning is only carried out as a routine fulfillment of the need to solve certain material only. Learning outcomes are only for preparing for passing exams or answering questions that are relevant to the material presented. In addition to not designing learning that begins with the right starting point, the concept of psychology learning views of the lecturer is also very minimal. The application of psychology views of learning is still minimal and understanding of the principles of each school of learning psychology is also very limited. Thus, the learning pattern becomes chaotic (distracted). Here it appears that the lecturer still does not understand the behavior should be explained through experience that can be observed, not by the mental process. Behavior is everything that is done and can be seen directly.

Preliminary research results are known, that the entering behavior that has been owned by the lecturers in the effort to make the design of learning systems, are: 1) have an understanding of learning theory; 2) have experience to design the learning system; 3) have an understanding of learning theory; 4) have basic skills to operate the computer; 5) have basic skills to integrate for learning and 6) have the ability to learn independently and learn in groups.

Based on the suggestions and comments of improvement from Education Technology experts, developers make improvements to the SIA module learning module design. Improvements include refinement of the purpose of writing specific learning, learning activities in the module should be oriented to constructivist approach, and learning materials that should be oriented to the ability to construct user module competencies in this case lecturers. The quality of the module presentation of the learning system module design that has been improved and declared feasible is then recommended for field trial.

The tools in the module are: (1) Guidance / guidance, outlining instructional activities, outlining units learned, learning activities, and learning evaluations; (2) sheets of learning activities, containing the formulation of learning objectives to be achieved, and Engin IJTRE 
a series of learning activities to be undertaken, and tasks to be performed; (3) worksheet, is a question or guidance on the implementation of work performance or project; (4) key worksheet, is the answer to the question or task performed; (5) test sheets, containing the questions to be done to measure the mastery level after the module has been studied; and (6) key test sheets, containing all the answers to the questions in the test.

Expert advice regarding the improvement of the module's carrying capacity towards student-centered or user-centered learning, based on the learning paradigm should be student centered in this case the lecturers as users. Module users are subject to learning, not learning objects. Therefore, the module's carrying capacity for learning should be described in detail, so what the module user should do in learning becomes clear. The paradigm of the student as a subject of learning refers to constructivism and concetual approach. Mastery of technology in learning by lecturers is a necessity, not only relevant to the basic principles of philosophy Technology Education facilitates people to learn, but also an obligation of lecturers in innovation of delivery. Mastery of technology is not only about proficiency of lecturers mastering the tools of technology, but more important is how lecturers are able to engineer technology into something that can facilitate their students to learn. The use of technology to improve student learning needs to be more than just knowledge of the latest use of hardwere and softwere. Demonstrate classes supported by, using presentation graphs to handle student learning styles, and designing lessons that require students to use technology as an investigation tool should be the hallmark of lecturers.

Expert validation results, module design The accounting information system developed has a material focus and presentation of the design of the learning system. In addition, the learning system design module The accounting information system developed meets the criteria and principles of learning technology aimed at facilitating and improving user performance. In the end this module can help facilitate the user in learning and developing competence as well as improve the ability and skills in designing the learning system.

Expert material validation results on the module content of the developed learning system design reflect the level of eligibility of the module to be used. Overall the material expert validation recommends that the materials in the module have been very good and feasible to be forwarded in the field trial process. This recommendation is the basis for conducting field trials. According to the expert, the level of material truth according to the field of scholarship and its relevance to general learning objectives (TPU) and specific learning objectives (T) has been relevant and excellent.

The evaluation stage is done by formative evaluation which is done: a) expert validation (expert review), b) one to one validation (1-1), c) small group validation, and d) validation of field trial (class experiment). Analytical techniques used are quantitative and qualitative. Quantitative data is data from questionnaires processed with excell while qualitative data with narration or words through data reduction, data presentation, and conclusion.

Taking into account the description of the module of learning system module SIA module development, it can be concluded that the learning objectives to be achieved have been in accordance with the desired learning objectives. According to the expert, that the specific purpose of learning in the module has been to the needs analysis, has relevance to the general objectives, and has been formulated specifically in accordance with the competence of the event. The specific purpose of learning has also been formulated and written differently for each different material.

The ability of modules to create effective learning independence is considered good. According to the expert, that giving congruent example of each material is able to grow the spirit and belief to the user to design the design of learning system according to the needs in its class. Thus, the use of SIA module learning system module by lecturers is one form.

Overall, both individual trials, small group trials, and field trials of serving sections in modules that are usable modules have been well received. The design of the design, the relevance of the learning materials, as well as the gradability and the extent of the media are well appreciated and can be used appropriately. Language elements in this case the use of sentences in the module easy to understand. The use of effective sentences aims to facilitate the user to understand the meaning contained in it. Effective use of sentences is relevant to the view, that the user more easily understand short sentences. One reason is that long sentences may exceed the memory range of the listener. Another reason is that long sentences usually contain conditional clauses, which are difficult to estimate and remember.

\section{CONCLUSION}

\section{A. Learning Sia At Informatics Department Upi Yai}

Based on these findings, the learning of Accounting Information System is still limited to the understanding of lesson plan (RPP), teaching materials, learning system design components, and limited competence standard (SK), basic competence (KD), and learning materials . Many lecturers do not mention the formulation of specific learning objectives, learning strategies, and assessment plans including making the program's grid and evaluation into the learning component. Thus it can be concluded that the current Accounting Information System learning that lecturers have not fully implemented the activities of designing the learning system as a whole and systematic.

Each component in the design of the learning system is still seen separately from one another. The design of learning components created has not been used as a basis for designing other learning components. The facts of the observations prove that the lecturer has not fully understood the concept and function of ICT and its relevance to other learning component in whole learning. 


\section{B. Approach Of Learning Sia In Informatics Department Upi Yai}

From the observation that basically the lecturer understand the concept of designing the learning system. However, in the application, lecturers have not been able to make the design of system learning in a good and systematic. The ability of computer mastery, lecturer who was observed entirely has been able to operate the computer. Lecturers have advanced computer skills, such as running power point applications, video editing programs, and accessing Internet networks. Thus it can be concluded that the approach used in the learning accounting information system (SIA) in the Department of Information Techniques UPI YAI current approach.

\section{Merging Learning Models On Sia}

Based on these findings it can be concluded that the incorporation of learning models on learning SIA with Dick and Carey learning patterns provide Every step is clear, so it can be followed. Organized, effective and efficient in the implementation. And it is a detailed model or learning plan, so it's easy to follow. On the other hand, there is a revision in the learning analysis, which is a very good thing, because if there is a mistake then immediately can be made changes to the instructional analysis, before the error in it also affect the error on the component afterwards. And Dick and Carey's models are very complete, almost everything that is needed in a learning plan.

\section{Effectiveness Of Sia Learning Merger}

Based on the results of the expert test, it can be concluded that the effectiveness of combining the learning model can not be separated from the 10 steps of the Dick and Carey learning model as follows: (1) determining what needs to be done so that students can do it when they have completed the learning program and set the general goal to be achieved. (2) determine what abilities are involved in the learning process to achieve goals and analyze the topics or materials to be studied. (3) Identify the initial behavior and characteristics of the students, when analyzing the skills that need to be trained or learned and the stages of the procedures that need to be passed, also considered the initial skills that students have. (4) Formulate performance goals or special goals. 5). Conduct the development of benchmark reference tests based on the objectives that have been formulated. (6) developing learning strategies to achieve the ultimate goal. (7) selecting or developing instructional materials including instructional instructions for students, materials, tests and lecturer guides. (8) to describe whether the program developed is good or not. If it does not have to be revised and if it has to be maintained. (9) see the usefulness of the program after being applied in the field. And (10) repeating system development cycle of learning system.

\section{ACKNOWLEDGEMENTS}

This research work is supported by Universitas Negeri Jakarta.

\section{REFERENCES}

[1] Branch, K. L. G. dan R. M. (2002). Survey of Instructional Development Models. Syracuse New York: ERIC Clearinghouse on Information \& Technology.

[2] Bruce Joyce, Marsha Weil, \& E. C. (2009). Models of Teaching Eight Edition. New York: pearson.

[3] Dick, W., Carey, L., \& Carey, J. (2009). The Systematic Design of Instruction. London: Pearson Education Ltd.

[4] Gustafson, Kent L. dan Branch, R. M. (2015). Survey of Instructional Development Models. 4th Edn. Syracus. New York: Eric Clearinghouse of Information and Technology, Syracus University.

[5] Ibrahim, N. (2010). Perspektif Pendidikan Terbuka Jarak Jauh. Jakarta: Bumi Aksara.

[6] Meredith D. Borg, Joyce P. Gall, W. R. (2007). Educational Research an Introduction eighth edition. Boston: pearson.

[7] Miarso, Y. (2009). Menyemai Benih Teknologi Pendidikan. Jakarta: Kencana Prenada Group.

[8] Prawiladilaga, D. S. (2012). Wawasan Teknologi Pendidikan Jakarta. Jakarta: Kencana Prenada Media Group.

[9] Reiser, R. A. (2007). Trend and Issues in Instructional Design and Technology. Upper Saddle River, NJ: Pearson Education.

[10] Semiawan, C. R. (2007). Catatan Kecil tentang Penelitian dan Pengembangan Ilmu Pengetahuan. Jakarta: Kencana Prenada Media Grup.

[11] Sharon E. Smaldino, D. L. L. J. D. S. (2012). Instructional Technology \& Media For Learning Teknologi Pembelajaran dan Media untuk Belajar. Penterjemah : Arif Rahman. (Kencana, Ed.). Jakarta.

[12] Sugiyono. (2015). Metode Penelitian Kuantitatif, Kualitatif, dan R \& D. Bandung: Alfabeta.

\section{AUTHORS PROFILE}

I am Endang Suparman, currently working with Department of Educational Technology Universitas Negeri Jakarta. my area of interest is education and living in RawamangunMuka Street, Rawamangun, Pulogadung, East Jakarta, 13220, Indonesia, and Lecturer at BRI Corporate University., endangsuparman264@gmail.com,

My name is Suyitno Muslim, affaliated with Department of Educational Technology Universitas Negeri Jakarta, RawamangunMuka Street, Rawamangun, Pulogadung, East Jakarta, 13220, suyitno@unj.ac.id,

Nurdin Ibrahim, Departmen of Educational Technology Universitas Negeri Jakarta, RawamangunMuka Street, Rawamangun, Pulogadung, East Jakarta, 13220,nurdin1349@yahoo.com,

Ayu Rahmayanti, is currently working with Departmen of Educational Technology Universitas Negeri Jakarta. my postl address is RawamangunMuka Street, Rawamangun, Pulogadung, East Jakarta, 13220, ayurahmayanti@gmail.com

i m Jhoni Lagun Siang, and Teacher at SMP Negeri 11 Tidore Kepulauan, J1. Lintas Halmahera, Kota Tidore Kepulauan, Maluku Utara, 97852, Indonesia,

jhonicinta@gmail.com 